\title{
Non-obstructive azoospermia: current and future perspectives
}

\author{
Tharu Tharakan ${ }^{1,2 X^{*}}$ Rong Luo ${ }^{1 \mathrm{X}} \quad$ Channa N. Jayasena ${ }^{1} \quad$ Suks Minhas $^{2}$ \\ ${ }^{1}$ Section of Investigative Medicine, Imperial College London, Hammersmith Hospital, London, United Kingdom \\ ${ }^{2}$ Department of Urology, Imperial Healthcare NHS Trust, Charing Cross Hospital, Fulham Palace Road, London, United Kingdom \\ $\mathrm{x}$ These authors contributed equally to the work
}

\begin{abstract}
Infertility affects 1 in 6 couples, and male factor infertility has been implicated as a cause in 50\% of cases. Azoospermia is defined as the absence of spermatozoa in the ejaculate and is considered the most extreme form of male factor infertility. Historically, these men were considered sterile but, with the advent of testicular sperm extraction and assisted reproductive technologies, men with azoospermia are able to biologically father their own children. Non-obstructive azoospermia (NOA) occurs when there is an impairment to spermatogenesis. This review describes the contemporary management of NOA and discusses the role of hormone stimulation therapy, surgical and embryological factors, and novel technologies such as proteomics, genomics, and artificial intelligence systems in the diagnosis and treatment of men with NOA. Moreover, we highlight that men with NOA represent a vulnerable population with an increased risk of developing cancer and cardiovascular comorbodities.
\end{abstract}

\section{Keywords}

Male infertility, azoospermia, genetics, artificial intelligence, sperm retrieval

\section{Peer Review}

The peer reviewers who approve this article are:

1. Sandro C Esteves, Androfert, Andrology \& Human Reproduction Clinic, and Department of Surgery (Division of Urology), University of Campinas (UNICAMP), Campinas, SP, Brazil

Competing interests: No competing interests were disclosed.

2. Vaibhav Modgil, Manchester Andrology Centre, Manchester Royal Infirmary, Manchester University Hospitals NHS Trust, Manchester, UK

Competing interests: No competing interests were disclosed.

3. Giovanni M. Colpi, Procrea Swiss Fertility Center, Andrology and IVF Department, Lugano, Switzerland Ettore Caroppo, ASL Bari PTA “F. Jaia”, Reproductive Unit, Conversano / Bari, Italy Competing interests: No competing interests were disclosed.

4. Selahittin Çayan, Department of Urology, Mersin University School of Medicine, Mersin, Turkey Competing interests: No competing interests were disclosed. 
*Corresponding author: Tharu Tharakan (tharu.tharakan@nhs.net)

Competing interests: The author(s) declare there are no competing interests.

Grant information: Tharu Tharakan has received funding from an Imperial Private Services Fellowship, and Channa N. Jayasena has received funding from an NIHR Post-Doctoral Fellowship. Channa N. Jayasena has received an investigator-led grant from Logixx Pharmaceuticals Ltd. The funders had no role in study design, data collection and analysis, decision to publish, or preparation of the manuscript.

Copyright: $(\odot 2021$ Tharakan T et al. This is an open access article distributed under the terms of the Creative Commons Attribution License, which permits unrestricted use, distribution, and reproductison in any medium, provided the original work is properly cited.

How to cite this article: Tharakan T, Luo R, Jayasena CN and Minhas S. Non-obstructive azoospermia: current and future perspectives. Faculty Reviews 2021 10:(7) https://doi.org/10.12703/r/10-7

Published: 26 Jan 2021, Faculty Reviews 10:(7) https://doi.org/10.12703/r/10-7 


\section{Introduction}

Infertility affects 1 in 6 couples, and male factor infertility has been implicated as a cause in $50 \%$ of cases ${ }^{1}$. Azoospermia is defined as the absence of spermatozoa in the ejaculate and is considered the most extreme form of male factor infertility. Historically, these men were considered sterile but, with the advent of testicular sperm extraction and assisted reproductive technology (ART), men with azoospermia are able to biologically father their own children. This review provides an up-to-date summary of current techniques used in the management of non-obstructive azoospermia (NOA) and highlights future areas of research.

\section{Definition and aetiology}

Azoospermia is classified as NOA or obstructive azoospermia (OA). NOA occurs when there is an impairment of spermatogenesis, whilst OA is caused by occlusion of the testicular and genital ductular system. NOA has been estimated to affect 1 in 100 men $^{2}$

The aetiology of NOA is conventionally categorised by the anatomical position of the cause: pre-testicular or testicular. Pre-testicular NOA (or secondary hypogonadism) arises because of a hormone abnormality such that a structurally normal testis is not stimulated effectively to produce sperm usually secondary to hypothalamic-pituitary disorders. Testicular azoospermia (or primary hypogonadism) relates to an intrinsic defect in the testicles leading to impaired spermatogenesis (Figure 1).

The histological features of NOA are classified into hypospermatogenesis, maturation arrest, and Sertoli-cell only (SCO). In hypospermatogenesis, germ cells of all stages of spermatogenesis are present but with a relative paucity in numbers. In maturation arrest, spermatogenesis is incomplete and halts at primary or secondary spermatocyte (early) or spermatid (late) stages. Therefore, mature spermatozoa are usually absent. SCO syndrome is characterised by a complete loss of germinal epithelium. It must be appreciated that in men with NOA, mixed histological patterns are common ${ }^{3}$.

\section{Management of NOA \\ Fertility aspects}

The use of gonadotrophin therapy is well established in pretesticular NOA (hypogonadotropic hypogonadism) and has been associated with natural conception within 6-9 months (although up to 24 months has been reported) from the onset of treatment ${ }^{4}$. There have been several retrospective case reports ${ }^{5-7}$ and ${\text { case } \text { series }^{8,9} \text { and a limited number of case control studies }}^{10-14}$ supporting the use of hormone stimulation in men with primary testicular NOA. Hussein et al. performed a prospective study of 612 patients with NOA and treated 496 men in the intervention group with clomiphene prior to sperm retrieval. The authors observed that $10.9 \%$ of men who received clomiphene had sperm in the ejaculate and did not require further surgical intervention ${ }^{10}$. However, the current literature is limited owing to heterogeneous methodology in terms of drugs used, treatment protocols, and cohort of patients. Furthermore, contemporary evidence is of low quality, with a paucity of randomised controlled trials. Therefore, the European Association of Urology (EAU) guidelines ${ }^{15}$ do not advocate the use of hormone therapy in men with NOA and primary hypogonadism, and the mainstay of treatment is testicular sperm extraction.

Historically, testicular sperm aspiration (TESA) and extraction (cTESE) involved random biopsies of testicular tissue.

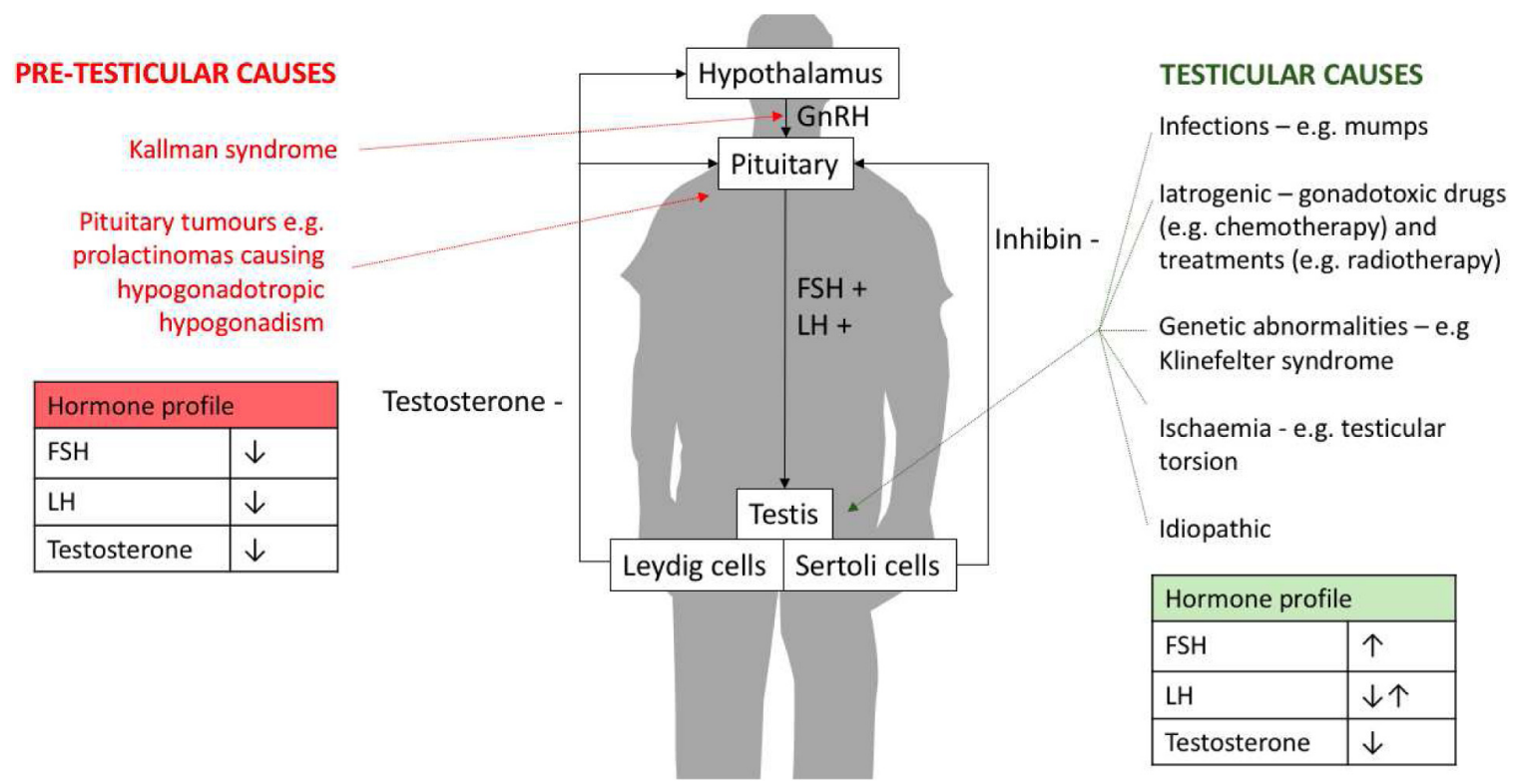

Figure 1. The causes and male reproductive hormone profiles associated with non-obstructive azoospermia. FSH, follicle-stimulating hormone; $\mathrm{GnRH}$, gonadotropin-releasing hormone; $\mathrm{LH}$, luteinising hormone. 
However, Schlegel pioneered the use of optical magnification to target specific seminiferous tubules that were more likely to contain spermatozoa ${ }^{16}$. These tubules are classically larger in size and more opaque than the majority of surrounding ones. An advantage of the use of optical magnification is it offers direct visualisation of testicular vessels and therefore minimises the risk of inadvertent vascular damage and potential hypogonadism. Consequently, microdissection testicular sperm extraction (mTESE) has been adopted as the optimal technique of surgical sperm retrieval. Schlegel reported that mTESE, compared with cTESE, removed far less testicular tissue (average mass of tissue removed in mTESE is $1.3 \%$ of cTESE) and was associated with a higher rate of successful sperm retrieval (50-60\% in mTESE versus $20-45 \%$ in cTESE) $)^{16}$. Similarly, Amer et al. observed that mTESE had a significantly higher sperm retrieval rate than CTESE $(47 \%$ versus $30 \%, P<0.05)$ despite a significantly lower volume of testicular tissue excised (4.65 mg versus $53.57 \mathrm{mg}, P<0.05)^{17}$. However, it must be noted that within the literature there is a paucity of studies comparing the amount of testicular tissue excised between cTESE and mTESE.

Bernie et al. performed a meta-analysis that compared the sperm retrieval rates in mTESE, cTESE, and TESA and observed that mTESE had the highest successful sperm retrieval rate. The authors also noted that mTESE had a 1.5 -fold higher sperm retrieval rate than did cTESE and cTESE had a 2-fold higher rate of sperm retrieval than did TESA $^{18}$. Successful sperm retrieval was associated with testicular histology, and hypospermatogenesis was observed to have the highest sperm retrieval rate $(73-100 \%)$, followed by late maturation arrest $(27-86 \%)$, early maturation arrest $(27-40 \%)$, and finally SCO $(22-41 \%)^{19,20}$. Surgical and biological factors have also been reported to influence sperm retrieval outcomes. Ishikawa et al. reported a higher sperm retrieval rate in a surgeon's second 50 mTESE procedures compared to their first 50 mTESE procedures (44\% versus $32 \%, P<0.05)^{21}$. Furthermore, Modarresi et al. observed that the additional use of enzymatic digestion (e.g. collagenase) yielded sperm in approximately $9 \%$ of cases where conventional mechanical extraction of sperm from testicular tissue had failed ${ }^{22}$. This suggests that there is a learning curve for both mTESE and also biological techniques, but it must be appreciated that surgical complications such as haematoma, fibrosis, and testicular atrophy have been reported to be less frequent in mTESE compared to $\mathrm{cTESE}^{20}$. In this setting, mTESE is considered the gold standard for surgical sperm retrieval, but it must be recognised that this technique does require more specialist expertise, longer procedure times, and higher operating costs compared to cTESE or TESA ${ }^{20}$. Whilst histological subtype and surgical method have been reported to be predictors of successful sperm retrieval, there is insufficient evidence to support both factors' use to discriminate between NOA men who should undergo surgical sperm retrieval surgery and those who should not ${ }^{23}$.

An alternative method of approaching surgical sperm retrieval in NOA is through identifying areas of spermatogenesis within the testicle via fine-needle aspiration (FNA). This process is known as testicular mapping ${ }^{24}$ and involves FNA at pre-determined sampling sites. The cytological results of testicular mapping are used to generate a geographical "heat map" of where spermatogenesis is present and subsequently used to guide further surgical sperm retrieval procedures in the form of either cTESE or mTESE at a secondary procedure. The advantages of testicular mapping are that it offers a methodical approach of assessing the whole testicle, thereby possibly reducing the likelihood of missing any areas of spermatogenesis. Beliveau and $\mathrm{Turek}^{24}$ reported in a cohort of 159 men with NOA who underwent testicular mapping a $90 \%$ chance of successful sperm retrieval using directed TESE in men who had 2 or more sites of spermatogenesis on a 18 sites/testicle map ${ }^{24}$. However, testicular mapping has been criticised because it does not extract viable sperm for intracytoplasmic sperm injection and therefore patients will need to undergo two separate procedures when only one may be required. Moreover, the need for two procedures will inevitably result in delays in subsequent ART procedures, which could prove detrimental given that increasing female age is associated with poorer outcomes ${ }^{25}$. The methodical value of mapping through FNA is also questionable, as, arguably, the systematic examination of a testicle under optical magnification with mTESE would achieve similar aims but with the additional yield of viable sperm, although randomised controlled studies are needed to substantiate this. Indeed, there is a paucity of studies investigating the use of FNA mapping in comparison to cTESE or MTESE, and there is also an absence of any cost-benefit analysis. In this setting, FNA mapping cannot be routinely advocated and further large-scale prospective randomised controlled trials are needed.

\section{Non-fertility aspects}

There is increasing evidence that male infertility is not only a risk factor for a decreased life expectancy and malignancy but also associated with a higher rate of cardiovascular comorbidities ${ }^{26}$. With reference to NOA, there are data showing that the prevalence of testicular cancer is $10.5 \%$ in men with SCO syndrome $^{27}$. Furthermore, Eisenberg et al. observed that azoospermic men (both NOA and OA) had a 2.2-fold increased risk of cancer compared to non-azoospermic men, with men younger than 30 being most susceptible ${ }^{28}$. Whilst the cause for this predisposition to cancer may be representative of the underlying aetiology of NOA (i.e. cryptorchidism confers an increased risk of testicular cancer $^{29}$ and Klinefelter syndrome patients are at increased risk of lung and breast cancer $^{30}$ ), in many cases the cause remains unknown. In such cases of idiopathic NOA, genetic factors have been postulated to be not only causative to the condition but also contributory to the increased susceptibility to cancer. In animal studies, it has been reported that abnormalities in DNA repair genes result in both azoospermia and malignancy ${ }^{31}$. Indeed, Anderson et al. observed in a retrospective cohort study consisting of over 25,000 men that both first- and second-degree relatives of azoospermic men had a significantly increased risk of thyroid cancer compared with fertile men $^{32}$. Whilst not specific to NOA, there are data linking the increasing incidence of testicular cancer, hypospadias, cryptorchidism, and male infertility secondary to in utero exposure to environmental endocrine-disrupting chemicals $^{33}$. This testicular dysgenesis syndrome may explain the association between testicular cancer and male infertility 
but not the association with other cancer subtypes, and further studies are needed to better characterise the association between NOA men and malignancy.

It is also important to recognise that because of the association of NOA with hypogonadism, this cohort of patients are at risk of osteoporosis, type 2 diabetes, obesity, and depression ${ }^{34}$.

Therefore, NOA men represent a vulnerable population with an increased risk of developing cancer and cardiovascular comorbodities. Within this context, clinicians must take a holistic approach when assessing NOA men to exclude other medical issues alongside the treatment of infertility, and it would seem logical to screen for testicular cancer by ultrasound and counsel these men regarding red flag symptoms and signs to prompt early referral. Similiarly, these patients should be screened for symptoms of hypogonadism, as they may be candidates for future testosterone replacement therapy. Indeed, the EAU guidelines recommend that all NOA patients should undego a comprehensive assessment, as this allows the identification and treatment of other comorbidies ${ }^{35}$.

\section{Emerging technologies and investigations}

In spite of the aforementioned advances in surgical techniques, the successful sperm retrieval rate is between 40 and $60 \%$ in men with $\mathrm{NOA}^{16}$. Within this context, novel technologies have been trialled to optimise sperm retrieval in NOA. There has been increasing interest in the ability to precisely and rapidly identify areas of focal spermatogenesis during testicular sperm extraction, although the majority of these studies are limited to ex vivo tissue and in vivo rodent studies.

Multiphoton microscopy (MPM) uses low energy infrared femtosecond pulsed lasers to induce excitation of molecules. Intracellular fluorophores such as NADPH, flavins, retinol, and tryptophan and its derivatives absorb energy from laser photons to become excited ${ }^{36}$. As it returns back to its ground state, the energy is released as autofluorescence. Combined with second harmonic generation by supramolecular structures, MPM can produce highly detailed imaging of deep underlying tissues (up to $400 \mu \mathrm{m}$ ) in real time with reduced damage to superficial tissues. In an ex vivo human testis study $(\mathrm{n}=7)$, concordance between MPM and traditionally stained slides was $86 \%{ }^{37}$. Ramasamy et al. used MPM to identify different stages of spermatogenesis in rodent testes via a single median incision similar to that of mTESE, noting differences in fluorescent attributes between tubules with spermatogenesis and those without ${ }^{38}$. Therefore, MPM could potentially optimise surgical techniques to identify tubules with spermatogenesis intraoperatively prior to making any biopsies and reduce the total number of testicular excisions necessary and subsequent risks of testicular atrophy and hypogonadism. However, there are significant barriers in current MPM technology before it can be applied to clinical use. MPM has a narrow field of view ${ }^{39}$, approximately $200 \mu \mathrm{m}$ in diameter, which is about the diameter of a single seminiferous tubule. At 4 frames per second, processing each tubule individually is tedious and would be subject to motion artefacts during in vivo applications, especially using portable MPM prototypes designed for intraoperative use ${ }^{40}$, although some mitigation is possible through an inbuilt tracking mechanism to compensate for the patient's movements ${ }^{41}$. Moreover, there are concerns over the mutagenic potential of lasers on spermatozoa ${ }^{37}$. A low power setting would be safer for spermatozoa but renders dim images that cannot be accurately interpreted ${ }^{37}$. In addition to this, the use of lasers in MPM would warrant extra safety precautions such as specialist theatres and laser safety goggles that offer protection against retinal damage $^{42}$. In addition, the invisible laser can be reflected unwittingly through reflective surfaces such as intraoperative surgical tools, rings, or glassware ${ }^{42}$.

Full field optical coherence tomography (FFOCT) uses white light interferometry to precisely examine the tomographic surface of a tissue specimen. The specimen is illuminated by a simple white light source, and optical beams of multiple wavelengths are reflected differentially depending on the subsurface features of the sample. The diffraction patterns, also known as waves, are used to decipher histology in real time (within a few minutes) without traditional fixing, staining, and processing, which is time consuming and tissue destructive. Currently, OCT technology is widely used in ophthalmology for the visualisation of the retina, but its ability for precise, non-invasive diagnostics lends itself to wider applications. In a pilot rodent study, FFOCT was successfully used to identify spermatogenesis in freshly excised testicular tissue ${ }^{43}$. The sensitivity and specificity of FFOCT are $80 \%$ and $95 \%$, respectively, of equivalent histological diagnosis ${ }^{44}$.

However, unlike MPM, FFOCT is limited to "en-face" superficial imaging with limited depth. Beyond the depth of 1-2 mm, light becomes scattered instead of being reflected. There is also an absence of cellular details to give structural context to the light signals produced by sperm tails ${ }^{43}$. However, the use of white light at eye-safe levels makes this process highly unlikely to cause damage to spermatozoa, especially since halogen lamps are already in use in operating rooms ${ }^{43}$. In a mTESE procedure, the freshly excised testicular tissue can be additionally scanned via FFOCT to confirm the presence of spermatogenesis intraoperatively prior to closing up the main incision. Almog et al. developed an endoscopic FFOCT system to perform in vivo neuroimaging experiments of a rat brain ${ }^{45}$, although no similar studies have yet been reported on testicular tissue.

Raman spectroscopy (RS) utilises the interaction of light with chemical bonds within a tissue sample to generate a spectra graph for each molecular structure. The unique scattering of light allows for distinction between different tissue types and identification of tubules with spermatogenesis. This has been demonstrated in ex vivo rodent and human studies, with a reported high specificity and sensitivity ${ }^{46,47}$. However, in contrast to the direct visual imaging techniques discussed above, RS relies on analytical interpretation of spectra results to deduce if spermatogenesis is present and to what extent. This therefore requires the creation of a customised algorithm that is able 
to reliably interpret different patterns of spectra peaks and correlate with underlying histology. Given the complexity of mixed histological patterns seen in NOA and the wide variation of cellular makeup of each individual, the creation, testing, and refining of such an algorithm is challenging.

\section{Novel genetic studies}

There is an impetus to understand the genes that contribute to the pathogenesis of NOA in order to help our understanding of the disease process and also to identify potential predictors for successful sperm retrieval. Spermatogenesis is a highly sensitive process and can be adversely affected by both environmental and genetic factors. The utilisation of mouse models has allowed the identification of more than 473 genes that contribute to male infertility ${ }^{48}$.

Currently, the use of chromosomal karyotype assays for Klinefelter syndrome and polymerase chain reaction analysis for azoospermia factor (AZF) microdeletions are established in clinical practice. Both of these tests are useful for diagnosing the underlying cause of NOA and critical for fertility counselling given that all $\mathrm{Y}$ chromosomal mutations will be inherited in future male offspring. With the exception of the AZF microdeletion, which can be found in $3-10 \%$ of men with NOA varying with population geography ${ }^{49,50}$, the frequency of the remaining monogenic mutations are too low for routine clinical testing. Men with complete AZFa or AZFb microdeletions have extremely poor sperm retrieval outcomes ${ }^{51,52}$. The sperm retrieval rate for $\mathrm{AZFc}$ microdeletions range between 33 and $87 \%$ owing to their wide phenotypic presentations ${ }^{53,54}$ (Table 1).

Beyond the identification of causal genes in NOA, comparative genomic and proteomic studies have been utilised to discover novel predictors of successful sperm retrieval. The majority of studies compare differential expression of selected genes or proteins in testicular biopsy samples or seminal plasma

Table 1. Genes or proteins that have been correlated with sperm retrieval rate.

\begin{tabular}{|c|c|c|c|c|}
\hline Name & Details & $\begin{array}{l}\text { SRR } \\
\text { outcomes }\end{array}$ & Additional information & Source \\
\hline \multicolumn{5}{|c|}{ Genetic markers using RT-PCR on testicular biopsies } \\
\hline \multirow[t]{3}{*}{ AZF } & $A Z F a-U S P 9 Y$ and $D B Y$ & Very poor & $\begin{array}{l}\text { Complete AZFa deletion causes Sertoli-cell only syndrome (SCOS) } \\
\text { Deletion of USP9Y only results in hypospermatogenesis }\end{array}$ & $\begin{array}{l}51 \\
55\end{array}$ \\
\hline & $\mathrm{AZFb}-\mathrm{RBMY}$ and $P R Y$ & Very poor & Corresponds with maturation arrest in histology & 52 \\
\hline & AZFC - 12 genes & $33-87 \%$ & $\begin{array}{l}\text { Common, wide phenotypic ranges from SCOS to } \\
\text { normospermatogenesis }\end{array}$ & $53,54,56$ \\
\hline JMJD1A & $\begin{array}{l}\text { Jumonji domain-containing } \\
\text { 1a }\end{array}$ & Positive & $\begin{array}{l}n=22 \\
\text { Sensitivity } 91 \% \text {, specificity } 89 \%\end{array}$ & 57 \\
\hline RNF8 & $\begin{array}{l}\text { E3 ubiquitin ligase } \\
\text { Chr } 6 \text { p21.3 }\end{array}$ & Positive & $\begin{array}{l}n=47 \\
\text { Sensitivity } 81 \% \text {, specificity } 84 \%\end{array}$ & 58 \\
\hline SPEM1 & $\begin{array}{l}\text { Post-meiotic marker, testes- } \\
\text { specific gene }\end{array}$ & Positive & $\begin{array}{l}n=63 \\
\text { Sensitivity } 96 \% \text {, specificity } 85 \%\end{array}$ & 59 \\
\hline VASA & $\begin{array}{l}\text { Chr } 5 q \text {, expressed } \\
\text { specifically in germ cells }\end{array}$ & Positive & $\begin{array}{l}n=52 \\
\text { Sensitivity } 87 \% \text {, specificity } 86 \% \\
\text { Independent predictor after multivariant analysis }\end{array}$ & 60 \\
\hline \multicolumn{5}{|c|}{ Protein markers in seminal plasma } \\
\hline Clusterin & $\begin{array}{l}\text { Apolipoprotein J, secreted } \\
\text { by Sertoli cells }\end{array}$ & Positive & $\begin{array}{l}\text { Seminal Clusterin in conjunction with FSH levels associated } \\
\text { with successful TESE }(n=89) \text {, with reduced risk of abnormal } \\
\text { spermatozoa and DNA fragmentation, although this may be } \\
\text { confounded by hypertension }\end{array}$ & $\begin{array}{l}61 \\
62 \\
63\end{array}$ \\
\hline LGAL3BP & $\begin{array}{l}\text { Lectin galactoside-binding, } \\
\text { soluble } 3 \text { binding protein }\end{array}$ & Positive & $\begin{array}{l}\text { Seminal LGAL3BP is higher in men with successful TESE } \\
n=40 \\
\text { Sensitivity } 100 \% \text {, specificity } 45 \%\end{array}$ & 64 \\
\hline HE1 & $\begin{array}{l}\text { Epididymal secretory } \\
\text { protein } \mathrm{E} 1 \text {, cholesterol } \\
\text { transporter }\end{array}$ & $\begin{array}{l}\text { Positive* } \\
\text { IVF }\end{array}$ & $\begin{array}{l}\text { Higher levels associated with successful IVF } \\
\mathrm{n}=13\end{array}$ & 65 \\
\hline TEX101 & $\begin{array}{l}\text { Cell membrane protein } \\
\text { exclusive to testicular germ } \\
\text { cell }\end{array}$ & Positive & $\begin{array}{l}n=137 \\
\text { Sensitivity } 73 \% \text {, specificity } 64 \% \\
\text { Proposed use of two marker algorithm ECM1 and TEX101 }\end{array}$ & $\begin{array}{l}66 \\
67\end{array}$ \\
\hline
\end{tabular}

FSH, follicle-stimulating hormone; IVF, in vitro fertilisation; RT-PCR, real-time polymerase chain reaction; SRR, sperm retrieval rate; TESE, testicular sperm extraction. 
(Table 1). However, seminal plasma has been adopted as the preferential choice because it can be obtained non-invasively and may more accurately reflect the microenvironment of the testes.

Whilst the above genetic markers have been reported to discriminate between successful and unsuccessful sperm retrieval, this does not necessarily equate to successful clinical pregnancy. Indeed, Dorosh et al. investigated the expression of markers associated with the final stages of spermatogenesis, ACR and GAPDHS, and observed that, despite high fertilisation rates of NOA patients with these markers $(71 \%$ and $66 \%$, respectively), clinical pregnancy was lower $(6 \%$ and $8 \%$, respectively) than the reported average NOA cohort $(26 \%)^{68}$.
Currently, the single most reliable predictor of sperm retrieval in NOA is histopathology. The presence of hypospermatogenesis was associated with higher rates of sperm retrieval (94\%) than maturation arrest $(37 \%)^{19,69}$. The lowest sperm retrieval rates are associated with a histological pattern of SCO syndrome $(24 \%)^{70-72}$. In this regard, the predominant histological subtype may be used to counsel men regarding the likelihood of a successful secondary surgical sperm retrieval procedure, although this has no value as a prognostic tool in predicting testicular sperm extraction at the time of a primary procedure.

Other non-invasive markers such as clinical and hormone parameters have been investigated as potential predictors of successful sperm retrieval (Table 2). However, the evidence for

\section{Table 2. Summary of biochemical and clinical predictors of sperm retrieval in non-obstructive azoospermia.}

\begin{tabular}{|c|c|}
\hline \multicolumn{2}{|c|}{ Hormonal factors } \\
\hline $\begin{array}{l}\text { Follicle- } \\
\text { stimulating } \\
\text { hormone (FSH) }\end{array}$ & $\begin{array}{l}\text { FSH is secreted by the pituitary to stimulate Sertoli cells, which support the spermatogenic process of germ cells in } \\
\text { men. An elevated FSH level has been associated with impaired spermatogenesis (Figure 1). Hence, some studies have } \\
\text { proposed that a high level of FSH could be a predictor of SRR in mTESE }{ }^{73,74} \text {. Yang et al. performed a meta-analysis of } \\
11 \text { studies that investigated FSH as a predictor of SRR prior to cTESE/mTESE. The AUC value of } 0.72 \text { was obtained } \\
\text { after pooled analysis, suggesting FSH to be a moderate predictor of SRR }{ }^{75} \text {. In contrast, Corona et al. }{ }^{76} \text { reported no } \\
\text { correlation between FSH levels and SRR after pooling } 117 \text { studies. These inconsistencies in the literature may be } \\
\text { explained by differences in surgical technique given that Yang's meta-analysis included studies predominantly using } \\
\text { cTESE (20/21), whilst Corona's meta-analysis included } 56 \text { studies using cTESE and } 43 \text { studies using mTESE. Indeed, } \\
\text { Ramasamy et al. observed in a large retrospective study of } 792 \text { men with NOA undergoing mTESE that SRRs were not } \\
\text { associated with FSH levels }{ }^{77} \text {. }\end{array}$ \\
\hline Inhibin B & $\begin{array}{l}\text { Inhibin B is produced by Sertoli cells and acts as a negative feedback regulator of FSH secretion. Therefore, inhibin } \\
\mathrm{B} \text { is a marker of spermatogenesis. High inhibin B levels in the serum or seminal plasma have been proposed to be an } \\
\text { independent predictor of SRR }{ }^{78} \text {. In a cohort of } 403 \mathrm{NOA} \text { men, higher inhibin B levels were associated with successful } \\
\text { SRR. The reported sensitivity was } 77.9 \% \text { and specificity was } 91.58 \% \text { (mixed cohort of mTESE and cTESE) } \\
\text { Vernaeve } \text { et } \text {. Yet observed in a cohort of } 185 \mathrm{NOA} \text { men that inhibin B was a poor discriminator of successul SRR } \\
\text { (cTESE) with a sensitivity of } 44.6 \% \text { and a specificity of } 63.4 \% \text {. Using ROC analysis, the authors observed an AUC of } \\
0.51 \text { for the inhibin B concentration of } 13.7 \mathrm{pg} / \mathrm{ml}^{80} \text {. Moreover, a meta-analysis comprising } 32 \text { studies reported that } \\
\text { serum inhibin B had a sensitivity of } 0.65 \text { and a specificity of } 0.83 \text { for predicting sperm retrieval in cTESE }{ }^{81} \text {. }\end{array}$ \\
\hline $\begin{array}{l}\text { Compo } \\
\text { marker }\end{array}$ & $\begin{array}{l}\text { Given the conflicting data regarding the utility of FSH and inhibin B individually as predictors of SRR, there have been } \\
\text { attempts to combine both hormone levels to increase the predictive power of these markers. Von Eckardstein et al. } .^{82} \\
\text { observed that together serum FSH and inhibin B levels were a more sensitive predictor of the state of spermatogenesis } \\
\text { than alone. However, collectively, these hormones predicted SRR from cTESE with a sensitivity of } 75 \% \text { and specificity } \\
\text { of } 73 \% \text {. Similarly, Vernaeve et al. performed a ROC analysis utilising both inhibin B and FSH and reported that the AUC } \\
\text { of inhibin B in men with an FSH level of }<25 \text { and } \geq 25 \text { IU/I (the best threshold value for discriminating successful and } \\
\text { unsuccessful cTESE was } 25 \mathrm{IU} / \mathrm{l} \text { ) was } 0.53 \text { and } 0.50 \text {, respectively }{ }^{80} \text {. } \\
\text { Boitrelle et al. combined testicular volume with serum FSH and inhibin B levels in a tri-variable predictive algorithm } \\
\text { to predict cTESE outcomes }{ }^{83} \text {. The authors reported that a score utilising these parameters was able to predict a } \\
\text { successful cTESE with a positive likelihood ratio of }+3.01 \text {. A score value of less than } 18.5 \text { correlated with a successful } \\
\text { cTESE in } 77.4 \% \text { of cases and live birth rate in } 41.8 \% \text { of cases. Moreover, this value was also predictive of a sperm yield } \\
\text { of greater than } 100 \text { spermatozoa in } 91.1 \% \text { of cases. }\end{array}$ \\
\hline Summary & $\begin{array}{l}\text { Within the context of the current literature, we cannot advocate a specific biochemical marker as a predictor of } \\
\text { successful SRR owing to conflicting data. }\end{array}$ \\
\hline \multicolumn{2}{|l|}{ Clinical factors } \\
\hline Patient age & $\begin{array}{l}\text { Amer et al. }{ }^{17} \text { investigated predictors of "difficult" (those with long durations, multiple biopsies required, and reduced } \\
\text { SRR) sperm retrieval operations (mixture of cTESE and mTESE). The authors reported that histological pattern, FSH } \\
\text { level, and testicular volume were not attributable. However, older age was a significant predictor and the mean age } \\
\text { (SD) in more difficult operations was } 39.4+/-7.95 \text { compared to } 32.75+/-6.76(P<0.05 \text { ) in those deemed less difficult. } \\
\text { Moreover, the duration of infertility was noted to be a significant discriminator with the more difficult operations having a } \\
\text { mean (SD) duration of } 9.8+/-6.1 \text { years compared to } 5.2+/-3.8 \text { years in those less difficult }(P<0.05) \text {. } \\
\text { Gnessi et al. observed that younger age was predictive of shorter procedure duration and faster recovery time. } \\
\text { However, this study reported that age was not predictive of cTESE outcome after multivariable analysis }{ }^{84} \text {. }\end{array}$ \\
\hline
\end{tabular}




\begin{tabular}{|c|c|}
\hline Smoking & $\begin{array}{l}\text { In a prospective study of } 64 \text { NOA men undergoing cTESE, tobacco use was observed to be an independent negative } \\
\text { predictor of SRR (odds ratio } 0.269, P=0.045)^{85} \text {. }\end{array}$ \\
\hline $\begin{array}{l}\text { Testicular } \\
\text { volume }\end{array}$ & $\begin{array}{l}\text { Testicular volume has been reported to be a predictor of SRR. Corona et al. observed in a meta-analysis comprising } \\
117 \text { studies (both mTESE and cTESE) that testicular volume was the only significant predictor of successful SRR. ROC } \\
\text { curve analysis for a testicular volume of }>12.5 \mathrm{ml} \text { predicted a SRR of }>60 \%{ }^{76} \text {. } \\
\text { However, caution must be applied to the above finding, as severe testicular atrophy does not exclude successful } \\
\text { mTESE outcomes. Bryson et al. reported a SRR of } 55 \% \text { with a testicular volume of }<2 \mathrm{ml}, 56 \% \text { with a testicular volume } \\
\text { of } 2-10 \mathrm{ml} \text {, and } 55 \% \text { with a testicular volume of }>10 \mathrm{ml} \text { in } 1,127 \text { patients }\end{array}$ \\
\hline Cryptorchidism & $\begin{array}{l}\text { A history of cryptorchidism was not associated with SRR in NOA men. Raman and Schlegel reported that the SRR } \\
\text { (mixed cohort of mTESE and cTESE) was } 74 \% \text { in the cryptorchid cohort }(n=35) \text { and } 58 \% \text { in the non-cryptorchid cohort } \\
(\mathrm{n}=274)^{87} \text {. Barbotin et al. observed no significant difference in SRR for cTESE between unilateral }(60 \%) \text { or bilateral } \\
\text { cryptorchidism }(66.2 \%), P=0.353^{88} \text {. }\end{array}$ \\
\hline
\end{tabular}

Previous failed Friedler et al. reported that, in repeated cTESE procedures, the successful SRR was 33/39 (85\%) and sperm could TESE attempts be found in men undergoing their fifth cTESE. Furthermore, there were no differences in fertilisation, implantation, or clinical pregnancy rate from sperm acquired from the first procedure and subsequent procedures ${ }^{89}$. Moreover, Kalsi et al. observed that repeat mTESE had no impact on SRR, as $40 \%$ of those with previous failed cTESE or TESA procedures were successful on repeat attempts ${ }^{90}$.

Embryological The embryological extraction process has been reported to impact on SRR.

factors Studies have reported that the addition of enzymatic treatment coupled with the conventional mincing method of testicular tissue confers a higher sperm yield ${ }^{22,91}$.

Surgical factors There is evidence that there is a learning curve for mTESE. Ishikawa et al. compared the SRR for a surgeon's first 50 mTESE procedures compared to the subsequent 50 procedures. There were no differences in the patient clinical factors between the two cohorts, but the operation times were shorter and the SRR was higher in the later operation group $(P<0.05)^{21}$.

AUC, area under the curve; cTESE, conventional (open) biopsies testicular sperm extraction; mTESE, microdissection testicular sperm extraction; NOA, nonobstructive azoospermia; ROC, receiver operating characteristic; SD, standard deviation; SRR, sperm retrieval rate; TESA, testicular sperm aspiration.

biochemical and clinical markers is conflicting. Serum hormone levels have been reported to be inaccurate markers of surgical sperm retrieval rates because they represent global testicular function rather than reflect the heterogenicity of testicular tissue ${ }^{92}$.

\section{Artificial intelligence in male fertility medicine}

The emergence of increasingly sophisticated computer technology combined with larger digital storage has allowed the generation of novel data acquisition. This large quantity of data requires processing in a timely and meaningful manner. Artificial intelligence (AI) is a branch of computer science that has been incorporated to assist in data analysis and can discern patterns among complex variables and formulate predictions through algorithms.

Recently, AI has been successfully applied in various medical fields that rely on image-based investigations such as radiology, gastroenterology, and oncology. In radiomics, AI was able to index patterns within medical imaging and apply algorithmic rules to accurately classify different radiographic patterns of disease $^{93}$. This includes not only the diagnosis of pathology but also prognosis and therapeutics ${ }^{94}$. Miotto, Kidd, and Dudley were able to use AI to predict the development of future medical conditions such as severe diabetes, schizophrenia, and various cancers in their patient population based on electronic heath records ${ }^{95}$. Gil et al. successfully used AI decision trees to predict semen quality in men based on environmental and lifestyle factors obtained through simple questionnaires with a reported accuracy of $86 \%^{96}$. Such tools could be useful for identifying men who are at risk of infertility and allow early targeted interventions such as lifestyle advice in a primary care setting. Many men with infertility were unaware of the impact of their adverse lifestyle decisions on their fertility ${ }^{97}$.

The role of AI in male infertility can be broadly classified into two areas: predictive modelling to enhance clinical decision making and optimisation of surgical procedures.

\section{Predictive modelling}

Predictive modelling may allow stratification of men who are more likely to have successful sperm retrieval prior to an mTESE procedure. Despite advances in sperm retrieval techniques, the success rate is only $50 \%^{76}$, and we are unable to reliably predict, and therefore counsel, which patient will likely benefit from surgery. Whilst there are inconsistencies in the literature regarding a single biomarker, it may be that a composite of two or more markers may be a more accurate predictor. Several studies have used multivariable regression analysis to develop predictive modelling to discriminate surgical sperm retrieval success. Cissen et al. reported that a prediction model based on several variables (male age, serum levels 
of luteinising hormone [LH], follicle-stimulating hormone $[\mathrm{FSH}]$, and testosterone, the diagnosis of idiopathic NOA, and the presence of an AZFc gene deletion) had an area under the receiver-operating characteristic (ROC) curve (AUC) of 0.69 . Moreover, the model was validated and identified to have a moderate discriminative value (AUC: 0.65). However, the authors noted that the study cohort had a disproportionately lower number of Klinefelter syndrome patients owing to governmental restrictions and thus there was selection bias ${ }^{98}$. Ma et al. ${ }^{99}$ developed a multivariable logistic model to predict the likelihood of sperm retrieval failure using TESA in NOA men. The authors reported that the predictive model had an AUC of $82.3 \%$ with a sensitivity of 0.677 and a specificity of 0.863 . However, this study was limited because some of the FNA results were misclassified.

AI has been utilised to rapidly analyse data and identify complex patterns. This has been tested by Ramasamy et al. using artificial neural networks (a new multivariate statistical model) to formulate new algorithms to predict sperm retrieval outcomes using a training set of 770 patients ${ }^{100}$. The information included was confined to clinical and biochemical markers such as FSH, age, and testicular volume, and the authors reported an accuracy of $59 \%{ }^{100}$

Chen and colleagues used artificial neural networks to predict sperm retrieval rates utilising 12 variables (testicular volume, semen volume, seminal $\mathrm{pH}$, seminal alpha glucosidase and fructose, serum FSH, LH, total testosterone, prolactin, oestradiol, and serum and seminal leptin ${ }^{101}$ ). The patient cohort comprised 280 NOA men undergoing cTESE. Three artificial neural network models were constructed and were observed to be a more accurate discriminator of successful sperm retrieval rate than FSH or leptin alone. Moreover, using ROC curve analysis, one of these models had an AUC of 0.83. However, whether the dataset size is large enough to allow accurate estimation of 12 variables is uncertain.

Zeadna et al. investigated the predictive capacity of models developed by machine learning (gradient boosted decision trees) and standard multivariate logistic regression to determine cTESE success. The variables studied were FSH, LH, testosterone, semen volume, age, body mass index, ethnicity, and testicular size ${ }^{102}$, and ROC curve analysis showed an AUC for the gradient boosted trees of 0.81 , whilst the AUC for the multivariate logistic regression model was 0.75 . However, the study was limited because it included a dataset consisting of only 119 patients.

More robust data sets, including the latest relevant genetic, proteomics, lifestyle, and environmental data, may allow AI algorithms to predict NOA men who are likely to develop malignancy and therefore help stratify a potential NOA screening population. This would result in obvious benefits in patient counselling and more effective use of health resources.

\section{Procedural optimisation}

AI and automation can simplify and expedite procedures. It can be a cost-effective way to boost standardisation of a process by eliminating human bias and reducing workforce. In the diagnostic workup for male infertility, semen analysis is performed according to WHO reference guidelines. In current practice, computer-aided sperm analysis (CASA) systems are able to report on motile percentage and kinematic parameters, allowing for high-throughput analysis ${ }^{103}$. Thirumalaraju et al. developed an artificial neural network that was reported to be able to accurately discriminate normal and abnormal sperm morphology with a sensitivity and specificity of $100 \%^{104}$. However, this was tested in a sample size of only nine ${ }^{104}$.

Robotic surgery represents another AI application in clinical medicine. The da Vinci robotic system allows for precision in microsurgical procedures, given that the instrumental arms offer an ability to rotate $540^{\circ}$, beyond the natural limits of a human hand. The robotic system also allows for high-resolution magnification. Although more commonly applied in laparoscopic abdominal surgeries, the technology can also be adapted in NOA. Parekattil and Gudeloglu performed 12 robotic-assisted mTESE without any complications ${ }^{105}$. A robotic platform would also be more amenable to incorporate modern imaging modalities such as MPM or FFOCT intraoperatively, overcoming some of the logistical barriers. Moreover, a robotic system could also offer virtual training modules ${ }^{106}$, telementoring, and long-distance telesurgery ${ }^{107}$. However, robotic systems come at a high expense in terms of both initial purchase and maintenance $\operatorname{costs}^{107}$.

\section{Conclusion}

The advent of testicular sperm extraction techniques has allowed men with NOA to father biological children. Whilst our understanding of the genetic and environmental mechanisms that underpin this disease expands, further research is needed to understand how to optimise surgical sperm retrieval rates and also discriminate between those in whom spermatogenesis is present and those in whom spermatogenesis is absent. Furthermore, it is now recognised that men with NOA are a vulnerable population that are at a higher risk of cancer and also other medical comorbidities. Therefore, the management of NOA should be holistic and address conditions outside the remit of male infertility.

Currently, there are significant inconsistencies in the literature regarding the role of both clinical and biochemical predictors of sperm retrieval outcomes, and further prospective, multi-centred trials are urgently required. There are emerging data highlighting the potential benefits of AI technologies in processing large collections of data to formulate algorithms that can be used to guide clinical management. Therefore, AI represents a promising tool to predict outcomes in NOA men and help patient counselling and healthcare resource management. 
1. Agarwal A, Mulgund A, Hamada A, et al:: A unique view on male infertility around the globe. Reprod Biol Endocrinol. 2015; 13: 37 PubMed Abstract | Publisher Full Text | Free Full Text

2. Jarow JP, Espeland MA, Lipshultz LI: Evaluation of the Azoospermic Patient. J Urol. 1989; 142(1): 62-5. PubMed Abstract | Publisher Full Text

3. McLachlan RI, Rajpert-De Meyts E, Hoei-Hansen CE, et al.: Histological evaluation of the human testis--approaches to optimizing the clinical value of the assessment: Mini review. Hum Reprod. 2007; 22(1): 2-16. PubMed Abstract | Publisher Full Text

4. Fraietta R, Zylberstejn DS, Esteves SC: Hypogonadotropic Hypogonadism Revisited. Clinics (Sao Paulo). 2013; 68 Suppl 1(Suppl 1): 81-8. PubMed Abstract | Publisher Full Text | Free Full Text

5. Selman HA, Cipollone G, Stuppia L, et al:: Gonadotropin treatment of an azoospermic patient with a Y-chromosome microdeletion. Fertil Steril. 2004; 82(1): 218-9.

PubMed Abstract | Publisher Full Text

6. Laursen RJ, Elbaek HO, Povlsen BB, et al:: Hormonal stimulation of spermatogenesis: A new way to treat the infertile male with non-obstructive azoospermia? Int Urol Nephrol. 2019; 51(3): 453-6. PubMed Abstract | Publisher Full Text | Faculty Opinions Recommendation

7. Zhao D, Pan L, Zhang F, et al.: Successful use of aromatase inhibitor letrozole in NOA with an elevated FSH level: A case report. Andrologia. 2014; 46(4): $456-7$.

PubMed Abstract | Publisher Full Text

8. Pavlovich $\mathrm{CP}$, King $\mathrm{P}$, Goldstein $\mathrm{M}$, et al:: Evidence of a treatable endocrinopathy in infertile men. J Urol. 2001; 165(3): 837-41.

PubMed Abstract | Publisher Full Text

9. Selman H, De Santo M, Sterzik K, et al.: Rescue of spermatogenesis arrest in azoospermic men after long-term gonadotropin treatment. Fertil Steril. 2006; 86(2): 466-8.

PubMed Abstract | Publisher Full Text

10. Hussein $A$, Ozgok $Y$, Ross $L$, et al.: Optimization of spermatogenesis-regulating hormones in patients with non-obstructive azoospermia and its impact on sperm retrieval: A multicentre study. BJU Int. 2013; 111(3 Pt B): E110-4. PubMed Abstract | Publisher Full Text

11. Majzoub A, Arafa M, Al Said S, et al:: Outcome of testicular sperm extraction in nonmosaic Klinefelter syndrome patients: What is the best approach? Andrologia. 2016; 48(2): 171-6.

PubMed Abstract | Publisher Full Text | Faculty Opinions Recommendation

12. Shiraishi K, Ohmi C, Shimabukuro T, et al:: Human chorionic gonadotrophin treatment prior to microdissection testicular sperm extraction in nonobstructive azoospermia. Hum Reprod. 2012; 27(2): 331-9. PubMed Abstract | Publisher Full Text | Faculty Opinions Recommendation

13. Cocci A, Cito G, Russo Gl, et al:: Effectiveness of highly purified urofollitropin treatment in patients with idiopathic azoospermia before testicular sperm extraction. Urologia. 2018; 85(1): 19-21. PubMed Abstract | Publisher Full Text | Faculty Opinions Recommendation

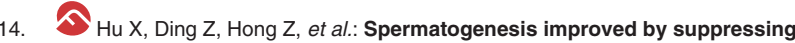
the high level of endogenous gonadotropins in idiopathic non-obstructive azoospermia: A case control pilot study. Reprod Biol Endocrinol. 2018; 16(1): 91.

PubMed Abstract | Publisher Full Text | Free Full Text |

Faculty Opinions Recommendation

15. Sexual and Reproductive Health Uroweb. Accessed June 14, 2020. Reference Source

16. Schlegel PN: Testicular sperm extraction: Microdissection improves sperm yield with minimal tissue excision. Hum Reprod. 1999; 14(1): 131-5. PubMed Abstract | Publisher Full Text

17. Amer M, Ateyah A, Zohdy W, et al:: Preoperative and intraoperative factors that predict difficult testicular sperm retrieval in patients with nonobstructive azoospermia. Fertil Steril. 2002; 78(3): 646-7. PubMed Abstract | Publisher Full Text

18. Cernie AM, Mata DA, Ramasamy R, et al:: Comparison of microdissection testicular sperm extraction, conventional testicular sperm extraction, and testicular sperm aspiration for nonobstructive azoospermia: A systematic review and meta-analysis. Fertil Steril. 2015; 104(5): 1099-103.e1-3. PubMed Abstract | Publisher Full Text | Faculty Opinions Recommendation

19. Caroppo E, Colpi EM, Gazzano G, et al.: Testicular histology may predict the successful sperm retrieval in patients with non-obstructive azoospermia undergoing conventional TESE: A diagnostic accuracy study. J Assist Reprod Genet. 2017; 34(1): 149-54.

PubMed Abstract | Publisher Full Text | Free Full Text

20. Deruyver $\mathrm{Y}$, Vanderschueren $\mathrm{D}$, van der Aa F: Outcome of microdissection TESE compared with conventional TESE in non-obstructive azoospermia: A systematic review. Andrology. 2014; 2(1): 20-4.

PubMed Abstract | Publisher Full Text | Faculty Opinions Recommendation

21. Ishikawa $\mathrm{T}$, Nose $\mathrm{R}$, Yamaguchi $\mathrm{K}$, et al:: Learning curves of microdissection testicular sperm extraction for nonobstructive azoospermia. Fertil Steril. 2010 94(3): 1008-11.

PubMed Abstract | Publisher Full Text

22. Modarresi T, Sabbaghian M, Shahverdi A, et al.: Enzymatic digestion improves testicular sperm retrieval in non-obstructive azoospermic patients. Iran Reprod Med. 2013; 11(6): 447-52.

PubMed Abstract | Free Full Tex

23. Arshad MA, Majzoub A, Esteves SC: Predictors of surgical sperm retrieval in non-obstructive azoospermia: Summary of current literature. Int Urol Nephrol. 2020; 52(11): 2015-38

PubMed Abstract | Publisher Full Text | Faculty Opinions Recommendation

24. Beliveau ME, Turek PJ: The value of testicular 'mapping' in men with nonobstructive azoospermia. Asian J Androl. 2011; 13(2): 225-30.

PubMed Abstract | Publisher Full Text | Free Full Text

25. Tan TY, Lau SK, Loh SF, et al.: Female ageing and reproductive outcome in assisted reproduction cycles. Singapore Med J. 2014; 55(6): 305-9. PubMed Abstract | Publisher Full Text | Free Full Text

26. Tharakan T, Bettocchi C, Carvalho J, et al:: Male Sexual and Reproductive Health-Does the Urologist Have a Role in Addressing Gender Inequality in Life Expectancy? Eur Urol Focus. 2020; 6(4): 791-800

PubMed Abstract | Publisher Full Text

27. Mancini M, Carmignani L, Gazzano G, et al.: High prevalence of testicular cancer in azoospermic men without spermatogenesis. Hum Reprod. 2007; 22(4): 1042-6.

PubMed Abstract | Publisher Full Text

28. Eisenberg ML, Betts $\mathrm{P}$, Herder $\mathrm{D}$, et al.: Increased risk of cancer among azoospermic men. Fertil Steril. 2013; 100(3): 681-5. PubMed Abstract | Publisher Full Text | Free Full Text | Faculty Opinions Recommendation

29. Pettersson A, Richiardi L, Nordenskjold A, et al.: Age at surgery for undescended testis and risk of testicular cancer. N Engl J Med. 2007; 356(18) 1835-41.

PubMed Abstract | Publisher Full Text | Faculty Opinions Recommendation

30. Burton A: Klinefelter's syndrome changes cancer risk. Lancet Oncol. 2005; 6(10): 741.

Publisher Full Text

31. Reitmair $\mathrm{AH}$, Schmits $\mathrm{R}$, Ewel $\mathrm{A}$, et al:: $\mathrm{MSH} 2$ deficient mice are viable and susceptible to lymphoid tumours. Nat Genet. 1995; 11(1): 64-70. PubMed Abstract | Publisher Full Text

32. Anderson RE, Hanson HA, Patel DP, et al.: Cancer risk in first- and seconddegree relatives of men with poor semen quality. Fertil Steril. 2016; 106(3): 731-8.

PubMed Abstract | Publisher Full Text | Free Full Text |

Faculty Opinions Recommendation

33. Skakkebaek NE, Rajpert-De Meyts E, et al:: Testicular dysgenesis syndrome: An increasingly common developmental disorder with environmental aspects. Hum Reprod. 2001; 16(5): 972-8.

PubMed Abstract | Publisher Full Text

34. Hackett G, Kirby M, Edwards D, et al.: UK policy statements on testosterone deficiency. Int J Clin Pract. 2017; 71(3-4): e12901.

PubMed Abstract | Publisher Full Text | Free Full Text

35. Professionals SO: Sexual and Reproductive Health. Uroweb. Accessed June 14, 2020.

Reference Source

36. Zipfel WR, Williams RM, Christie R, et al:: Live tissue intrinsic emission microscopy using multiphoton-excited native fluorescence and second harmonic generation. Proc Natl Acad Sci U S A. 2003; 100(12): 7075-80. PubMed Abstract | Publisher Full Text | Free Full Text

37. Najari BB, Ramasamy R, Sterling J, et al:: Pilot study of the correlation of multiphoton tomography of ex vivo human testis with histology. J Urol. 2012 188(2): 538-43.

PubMed Abstract | Publisher Full Text

38. Ramasamy R, Sterling J, Fisher ES, et al:: Identification of spermatogenesis with multiphoton microscopy: An evaluation in a rodent model. $J$ Urol. 2011; 186(6): 2487-92.

PubMed Abstract | Publisher Full Text

39. Katz MJ, Huland DM, Ramasamy R: Multiphoton microscopy: Applications in Urology and Andrology. Transl Androl Urol. 2014; 3(1): 77-83. PubMed Abstract | Publisher Full Text | Free Full Text

40. Huland DM, Brown CM, Howard SS, et al: In vivo imaging of unstained tissues using long gradient index lens multiphoton endoscopic systems. Biomed Op Express. 2012; 3(5): 1077-85.

PubMed Abstract | Publisher Full Text | Free Full Text 
41. Sherlock B, Warren S, Stone J, et al:: Fibre-coupled multiphoton microscope with adaptive motion compensation. Biomed Opt Express. 2015; 6(5): 1876-84. PubMed Abstract | Publisher Full Text | Free Full Text

42. Marshall J: The safety of laser pointers: Myths and realities. Br J Ophthalmol. 1998; 82(11): 1335-8.

PubMed Abstract | Publisher Full Text | Free Full Text

43. Ramasamy R, Sterling J, Manzoor M, et al.: Full field optical coherence tomography can identify spermatogenesis in a rodent sertoli-cell only model. J Pathol Inform. 2012; 3: 4 .

PubMed Abstract | Publisher Full Text | Free Full Text

44. Thouvenin O, Apelian C, Nahas A, et al.: Full-Field Optical Coherence Tomography as a Diagnosis Tool: Recent Progress with Multimodal Imaging. Applied Sciences. 2017; 7(3): 236. Publisher Full Text

45. Almog IF, Chen FD, Senova S, et al.: Full-field swept-source optical coherence tomography and neural tissue classification for deep brain imaging. J Biophotonics. 2020; 13(2): e201960083. PubMed Abstract | Publisher Full Text | Free Full Text | Faculty Opinions Recommendation

46. Liu Y, Zhu Y, Di L, et al.: Raman spectroscopy as an ex vivo noninvasive approach to distinguish complete and incomplete spermatogenesis within human seminiferous tubules. Fertil Steril. 2014; 102(1): 54-60.e2. PubMed Abstract | Publisher Full Text

47. Osterberg EC, Laudano MA, Ramasamy R, et al:: Identification of spermatogenesis in a rat sertoli-cell only model using Raman spectroscopy: A feasibility study. J Urol. 2014; 192(2): 607-12.

PubMed Abstract | Publisher Full Text

48. Matzuk MM, Lamb DJ: The biology of infertility: Research advances and clinical challenges. Nat Med. 2008; 14(11): 1197-213. PubMed Abstract | Publisher Full Text | Free Full Text

49. Akınsal EC, Baydilli N, Dündar M, et al:: The frequencies of $\mathrm{Y}$ chromosome microdeletions in infertile males. Turk J Urol. 2018; 44(5): 389-92. PubMed Abstract | Publisher Full Text | Free Full Text | Faculty Opinions Recommendation

50. Kim SY, Lee BY, Oh AR, et al:: Clinical, Hormonal, and Genetic Evaluation of Idiopathic Nonobstructive Azoospermia and Klinefelter Syndrome Patients. Cytogenet Genome Res. 2017; 153(4): 190-7. PubMed Abstract | Publisher Full Text

51. Kamp C, Huellen K, Fernandes S, et al.: High deletion frequency of the complete AZFa sequence in men with Sertoli-cell-only syndrome. Mol Hum Reprod. 2001; 7(10): 987-94.

PubMed Abstract | Publisher Full Text

52. Repping S, Skaletsky H, Lange J, et al:: Recombination between palindromes $\mathrm{P} 5$ and $\mathrm{P} 1$ on the human $\mathrm{Y}$ chromosome causes massive deletions and spermatogenic failure. Am J Hum Genet. 2002; 71(4): 906-22. PubMed Abstract | Publisher Full Text | Free Full Tex

53. Hopps CV, Mielnik A, Goldstein M, et al.: Detection of sperm in men with $\mathbf{Y}$ chromosome microdeletions of the AZFa, AZFb and AZFc regions. Hum Reprod. 2003; 18(8): 1660-5.

PubMed Abstract | Publisher Full Text

54. Johnson M, Raheem A, de Luca F, et al.: An analysis of the frequency of Y-chromosome microdeletions and the determination of a threshold sperm concentration for genetic testing in infertile men. BJU Int. 2019; 123(2): 367-72. PubMed Abstract | Publisher Full Text | Faculty Opinions Recommendation

55. Luddi A, Margollicci M, Gambera L, et al.: Spermatogenesis in a man with complete deletion of USP9Y. N Engl J Med. 2009; 360(9): 881-5. PubMed Abstract | Publisher Full Text | Faculty Opinions Recommendation

56. Silber SJ: The $\mathbf{Y}$ chromosome in the era of intracytoplasmic sperm injection: A personal review. Fertil Steril. 2011; 95(8): 2439-48.e1-5. PubMed Abstract | Publisher Full Text

57. Eelaminejad Z, Favaedi R, Modarresi T, et al.: Association between JMJD1A Expression and Sperm Retrieval in Non-Obstructive Azoospermic Patients. Cell J. 2018; 19(4): 660-665.

PubMed Abstract | Publisher Full Text | Free Full Text |

Faculty Opinions Recommendation

58. Nazari M, Babakhanzadeh E, Mohsen Aghaei Zarch S, et al.: Upregulation of the RNF8 gene can predict the presence of sperm in azoospermic individuals. Clin Exp Reprod Med. 2020; 47(1): 61-67. PubMed Abstract | Publisher Full Text | Free Full Text | Faculty Opinions Recommendation

59. Hashemi MS, Mozdarani H, Ghaedi K, et al:: Among seven testis-specific molecular markers, SPEM1 appears to have a significant clinical value for prediction of sperm retrieval in azoospermic men. Andrology. 2018; 6(6): 890-5. PubMed Abstract | Publisher Full Text | Faculty Opinions Recommendation

60. Ando M, Yamaguchi $\mathrm{K}$, Chiba $\mathrm{K}$, et al.: Expression of VASA mRNA in testis as a significant predictor of sperm recovery by microdissection testicular sperm extraction in patient with nonobstructive azoospermia. J Androl. 2012; 33(4): 711-6.

PubMed Abstract | Publisher Full Text

61. Fukuda $\mathrm{T}$, Miyake $\mathrm{H}$, Enatsu $\mathrm{N}$, et al.: Seminal level of clusterin in infertile men as a significant biomarker reflecting spermatogenesis. Andrologia. 2016; 48(10): 1188-94.

PubMed Abstract | Publisher Full Text

62. Salehi M, Akbari $\mathrm{H}$, Heidari $\mathrm{MH}$, et al:: Correlation between human clusterin in seminal plasma with sperm protamine deficiency and DNA fragmentation. Mol Reprod Dev. 2013; 80(9): 718-24.

PubMed Abstract | Publisher Full Text

63. Muciaccia B, Pensini S, Culasso F, et al:: Higher clusterin immunolabeling and sperm DNA damage levels in hypertensive men compared with controls. Hum Reprod. 2012; 27(8): 2267-76.

Hum Reprod. 2012; 27(8): 2267-76.
PubMed Abstract | Publisher Full Text | Faculty Opinions Recommendation

64. Freour $\mathrm{T}$, Com $\mathrm{E}$, Barriere $\mathrm{P}$, et al:: Comparative proteomic analysis coupled with conventional protein assay as a strategy to identify predictors of successful testicular sperm extraction in patients with non-obstructive azoospermia. Andrology. 2013; 1(3): 414-20. PubMed Abstract | Publisher Full Text

65. Kanannejad Z, Gharesi-Fard B: Difference in the seminal plasma protein expression in unexplained infertile men with successful and unsuccessful in vitro fertilisation outcome. Andrologia. 2019; 51(1): e13158. PubMed Abstract | Publisher Full Text | Faculty Opinions Recommendation

66. Korbakis D, Schiza C, Brinc D, et al.: Preclinical evaluation of a TEX101 protein ELISA test for the differential diagnosis of male infertility. BMC Med. 2017; 15(1): 60.

PubMed Abstract | Publisher Full Text | Free Full Text

67. Drabovich AP, Saraon $\mathrm{P}$, Jarvi K, et al:: Seminal plasma as a diagnostic fluid for male reproductive system disorders. Nat Rev Urol. 2014; 11(5): 278-88. PubMed Abstract | Publisher Full Text

68. Dorosh A, Tepla O, Zatecka E, et al.: Expression analysis of MND1/GAJ, SPATA22, GAPDHS and ACR genes in testicular biopsies from nonobstructive azoospermia (NOA) patients. Reprod Biol Endocrinol. 2013; 11: 42. PubMed Abstract | Publisher Full Text | Free Full Text

69. Abdel Raheem A, Garaffa G, Rushwan N, et al.: Testicular histopathology as a predictor of a positive sperm retrieval in men with non-obstructive azoospermia. BJU Int. 2013; 111(3): 492-9. PubMed Abstract | Publisher Full Text

70. Kalsi J, Thum MY, Muneer A, et al:: In the era of micro-dissection sperm retrieval ( $m$-TESE) is an isolated testicular biopsy necessary in the management of men with non-obstructive azoospermia? BJU Int. 2012; 109(3): 418-24.

PubMed Abstract | Publisher Full Text

71. Schoor RA, Elhanbly S, Niederberger CS, et al.: The role of testicular biopsy in the modern management of male infertility. J Urol. 2002; 167(1): 197-200. PubMed Abstract | Publisher Full Text

72. Esteves SC, Prudencio C, Seol B, et al: Comparison of sperm retrieval and reproductive outcome in azoospermic men with testicular failure and obstructive azoospermia treated for infertility. Asian J Androl. 2014; 16(4): 602-6.

PubMed Abstract | Publisher Full Text | Free Full Text

73. Salehi $P$, Derakhshan-Horeh $M$, Nadeali $Z$, et al.: Factors influencing sperm retrieval following testicular sperm extraction in nonobstructive azoospermia patients. Clin Exp Reprod Med. 2017; 44(1): 22-7. PubMed Abstract | Publisher Full Text | Free Full Text

74. Jahromi BN, Zeyghami S, Parsanezhad ME, et al.: Determining an optimal cut-off value for follicle-stimulating hormone to predict microsurgical testicular sperm extraction outcome in patients with non-obstructive azoospermia. Arch Endocrinol Metab. 2020; 64(2): 165-70. PubMed Abstract | Publisher Full Text | Faculty Opinions Recommendation

75. Yang Q, Huang YP, Wang HX, et al.: Follicle-stimulating hormone as a predictor for sperm retrieval rate in patients with nonobstructive azoospermia: A systematic review and meta-analysis. Asian J Androl. 2015; 17(2): 281-4. PubMed Abstract | Publisher Full Text | Free Full Text

76. Corona G, Minhas S, Giwercman A, et al:: Sperm recovery and ICSI outcomes in men with non-obstructive azoospermia: A systematic review and meta-analysis. Hum Reprod Update. 2019; 25(6): 733-57. PubMed Abstract | Publisher Full Text

77. Ramasamy R, Lin K, Gosden LV, et al.: High serum FSH levels in men with nonobstructive azoospermia does not affect success of microdissection testicular sperm extraction. Fertil Steril. 2009; 92(2): 590-3. PubMed Abstract | Publisher Full Text | Faculty Opinions Recommendation

78. Nagata Y, Fujita K, Banzai J, et al.: Seminal plasma inhibin-B level is a useful predictor of the success of conventional testicular sperm extraction in patients with non-obstructive azoospermia. J Obstet Gynaecol Res. 2005; 31(5): 384-8.

PubMed Abstract | Publisher Full Text

79. Zhu ZG, Zhao ZG, Pang QY, et al:: Predictive significance of serum inhibin $B$ on testicular haploid gamete retrieval outcomes in nonobstructive azoospermic men. Asian J Androl. 2019; 21(2): 137-42. azoospermic men. Asian J Androl. 2019; 21(2): 137-42.
PubMed Abstract | Publisher Full Text | Free Full Text | Faculty Opinions Recommendation

80. Vernaeve $\mathrm{V}$, Tournaye $\mathrm{H}$, Schiettecatte $\mathrm{J}$, et al:: Serum inhibin B cannot predict testicular sperm retrieval in patients with non-obstructive azoospermia. Hum 
Reprod. 2002; 17(4): 971-6. PubMed Abstract | Publisher Full Text

81. Toulis KA, lliadou PK, Venetis CA, et al.: Inhibin B and anti-Mullerian hormone as markers of persistent spermatogenesis in men with non-obstructive azoospermia: A meta-analysis of diagnostic accuracy studies. Hum Reprod Update. 2010; 16(6): 713-24.

PubMed Abstract | Publisher Full Text

82. von Eckardstein $\mathrm{S}$, Simoni M, Bergmann $\mathrm{M}$, et al.: Serum inhibin $\mathrm{B}$ in combination with serum follicle-stimulating hormone (FSH) is a more sensitive marker than serum FSH alone for impaired spermatogenesis in men, but cannot predict the presence of sperm in testicular tissue samples. $J$ Clin Endocrinol Metab. 1999; 84(7): 2496-501.

PubMed Abstract | Publisher Full Text

83. Boitrelle F, Robin G, Marcelli F, et al:: A predictive score for testicular sperm extraction quality and surgical ICSI outcome in non-obstructive azoospermia: A retrospective study. Hum Reprod. 2011; 26(12): 3215-21. PubMed Abstract | Publisher Full Text

84. C Gnessi L, Scarselli F, Minasi MG, et al.: Testicular histopathology, semen analysis and FSH, predictive value of sperm retrieval: supportive counseling in case of reoperation after testicular sperm extraction (TESE). BMC Urol. 2018; 18(1): 63.

PubMed Abstract | Publisher Full Text | Free Full Text | Faculty Opinions Recommendation

85. Pavan-Jukic D, Stubljar D, Jukic T, et al.: Predictive factors for sperm retrieval from males with azoospermia who are eligible for testicular sperm extraction (TESE). Syst Biol Reprod Med. 2020; 66(1): 70-5. PubMed Abstract | Publisher Full Text | Faculty Opinions Recommendation

86. - Bryson CF, Ramasamy R, Sheehan M, et al:: Severe testicular atrophy does not affect the success of microdissection testicular sperm extraction. $J$ Urol. 2014; 191(1): 175-8.

PubMed Abstract | Publisher Full Text | Free Full Text |

Faculty Opinions Recommendation

87. Raman JD, Schlegel PN: Testicular sperm extraction with intracytoplasmic sperm injection is successful for the treatment of nonobstructive azoospermia associated with cryptorchidism. J Urol. 2003; 170(4 Pt 1): 1287-90. PubMed Abstract | Publisher Full Text

88. Barbotin AL, Dauvergne A, Dumont A, et al.: Bilateral versus unilateral cryptorchidism in nonobstructive azoospermia: Testicular sperm extraction outcomes. Asian J Androl. 2019; 21(5): 445-51

PubMed Abstract | Publisher Full Text | Free Full Text | Faculty Opinions Recommendation

89. Friedler S, Raziel A, Schachter M, et al:: Outcome of first and repeated testicula sperm extraction and ICSI in patients with non-obstructive azoospermia. Hum Reprod. 2002; 17(9): 2356-61. PubMed Abstract | Publisher Full Text

90. Kalsi JS, Shah P, Thum Y, et al.: Salvage micro-dissection testicular sperm extraction; outcome in men with non-obstructive azoospermia with previous failed sperm retrievals. BJU Int. 2015; 116(3): 460-5. PubMed Abstract | Publisher Full Text

91. Crabbé E, Verheyen G, Silber S, et al.: Enzymatic digestion of testicular tissue may rescue the intracytoplasmic sperm injection cycle in some patients with non-obstructive azoospermia. Hum Reprod. 1998; 13(10): 2791-6. PubMed Abstract | Publisher Full Text

92. Robay A, Abbasi S, Akil A, et al:: A systematic review on the genetics of male infertility in the era of next-generation sequencing. Arab J Urol. 2018; 16(1): 53-64.

PubMed Abstract | Publisher Full Text | Free Full Text |

Faculty Opinions Recommendation
93.

Giger ML: Machine Learning in Medical Imaging. J Am Coll Radiol. 2018; 15(3 Pt B): 512-20.

PubMed Abstract | Publisher Full Text | Faculty Opinions Recommendation

94. Bibault JE, Giraud P, Housset M, et al.: Deep Learning and Radiomics predict complete response after neo-adjuvant chemoradiation for locally advanced rectal cancer. Sci Rep. 2018; 8(1): 12611

PubMed Abstract | Publisher Full Text | Free Full Text

Fubulty Opinions Recommendation

95. Miotto R, Li L, Kidd BA, et al.: Deep Patient: An Unsupervised Representation to Predict the Future of Patients from the Electronic Health Records. Sci Rep. 2016; 6: 26094.

PubMed Abstract | Publisher Full Text | Free Full Text

96. Gil D, Girela JL, de Juan J, et al:: Predicting seminal quality with artificial intelligence methods. Expert Systems with Applications. 2012; 39(16): 12564-73. Publisher Full Text

97. Jayasena CN, Sharma A, Abbara A, et al.: Burdens and awareness of adverse self-reported lifestyle factors in men with sub-fertility: A cross-sectional study in 1149 men. Clin Endocrinol (Oxf). 2020; 93(3): 312-321. PubMed Abstract | Publisher Full Text

98. Cissen M, Meijerink AM, D'Hauwers KW, et al:: Prediction model for obtaining spermatozoa with testicular sperm extraction in men with non-obstructive azoospermia. Hum Reprod. 2016; 31(9): 1934-41. PubMed Abstract | Publisher Full Text | Faculty Opinions Recommendation

99. $\mathrm{Ma} Y, \mathrm{Li} F$, Wang $\mathrm{L}$, et al.: A risk prediction model of sperm retrieval failure with fine needle aspiration in males with non-obstructive azoospermia. Hum Reprod. 2019; 34(2): 200-8.

PubMed Abstract | Publisher Full Text | Free Full Text |

Faculty Opinions Recommendation

100. Ramasamy R, Padilla WO, Osterberg EC, et al:: A comparison of models for predicting sperm retrieval before microdissection testicular sperm extraction in men with nonobstructive azoospermia. J Urol. 2013; 189(2): 638-42. PubMed Abstract | Publisher Full Text

101. Ma $\mathrm{Y}$, Chen $\mathrm{B}$, Wang $\mathrm{H}$, et al.: Prediction of sperm retrieval in men with nonobstructive azoospermia using artificial neural networks: Leptin is a good assistant diagnostic marker. Hum Reprod. 2011; 26(2): 294-8. PubMed Abstract | Publisher Full Text

102. Zeadna A, Khateeb N, Rokach L, et al.: Prediction of sperm extraction in non-obstructive azoospermia patients: A machine-learning perspective. Hum Reprod. 2020; 35(7): 1505-1514.

PubMed Abstract | Publisher Full Text | Faculty Opinions Recommendation

103. Goodson SG, White S, Stevans AM, et al.: CASAnova: A multiclass support vector machine model for the classification of human sperm motility patterns. Biol Reprod. 2017; 97(5): 698-708.

PubMed Abstract | Publisher Full Text | Free Full Text

104. Thirumalaraju $\mathrm{P}$, Bormann CL, Kanakasabapathy M, et al.: Automated sperm morphology testing using artificial intelligence. Fertil Steril. 2018; 110(4): e432. Publisher Full Text

105. Parekattil SJ, Gudeloglu A: Robotic assisted andrological surgery. Asian J Androl. 2013; 15(1): 67-74.

PubMed Abstract | Publisher Full Text | Free Full Text

106. Sridhar AN, Briggs TP, Kelly JD, et al.: Training in Robotic Surgery-an Overview. Curr Urol Rep. 2017; 18(8): 58 PubMed Abstract | Publisher Full Text | Free Full Text

107. George El, Brand TC, LaPorta A, et al:: Origins of Robotic Surgery: From Skepticism to Standard of Care. JSLS. 2018; 22(4): e2018.00039. PubMed Abstract | Publisher Full Text | Free Full Text |

Faculty Opinions Recommendation 